\title{
Earnings Management and Different Tax Book To Explain Earnings Persistency
}

\section{Ni Ketut Lely Aryani Merkusiwati ${ }^{1}$ \\ Fakultas Ekonomi dan Bisnis \\ Universitas Udayana, Indonesia. \\ Email: lelyaryanimer@unud.ac.id}

\author{
I Gusti Ayu Eka Damayanthi \\ Fakultas Ekonomi dan Bisnis \\ Universitas Udayana, Indonesia.
}

\begin{abstract}
ABSTRAK
The study aims to test the direct and indirect effects of earnings management on earnings persistence through different tax books. Opportunistic earnings management results can reduced persistence of accruals. A decrease in accrual persistence will reduce earnings persistence. Different book tax variable were added as an alternative explanation. Earnings management can increase the book tax different reported by the company. A high tax different book can also reduce earnings persistence. A high tax different book is a signal of poor earnings quality. The population of this study is companies listed on the Indonesia Stock Exchange. The sample of this research is manufacturing companies listed on the Indonesia Stock Exchange Data analysis methods used in this study were descriptive statistics and path analysis. The path analysis results prove that there is the indirect effect of earnings management on earnings persistence through different tax books. The results of the study prove that there is no the direct influence of earnings management on earnings persistence.
\end{abstract}

Keywords: $\quad$ Book Tax Different; Earnings Management; Earnings Persistency.

\section{Manajemen Laba dan Book Tax Different Untuk Menjelaskan Persistensi Laba}

\begin{abstract}
ABSTRAK
Penelitian ini meneliti pengaruh langsung dan tidak langsung manajemen laba pada persistensi laba melalui book tax different. Manajemen laba yang oportunistik mengakibatkan menurunkan persistensi akrual. Penurunan persistensi akrual akan menurunkan persistensi laba. Penelitian ini menambahkan variabel book tax different sebagai penjelasan alternatif. Manajemen laba akan meningkatkan book tax different yang dilaporkan oleh perusahaan. Book tax different yang tinggi akan menurunkan persistensi laba. Book tax different yang tinggi merupakan sinyal kualitas laba yang buruk. Populasi penelitian ini adalah perusahaan yang terdaftar di Bursa Efek Indonesia. Sampel penelitian ini adalah perusahaan manufaktur yang terdaftar di Bursa Efek Indonesia. Metode analisis data yang dipergunakan dalam penelitian ini adalah statistik deskriptif dan analisis jalur. Hasil analisis Jalur membuktikan pengaruh tidak langsung manajemen laba pada persistensi laba melalui book tax different. Hasil penelitian tidak membuktikan pengaruh langsung manajemen laba pada persistensi laba.
\end{abstract}

Kata Kunci: Book Tax Different; Manajemen Laba; Persistensi Laba.

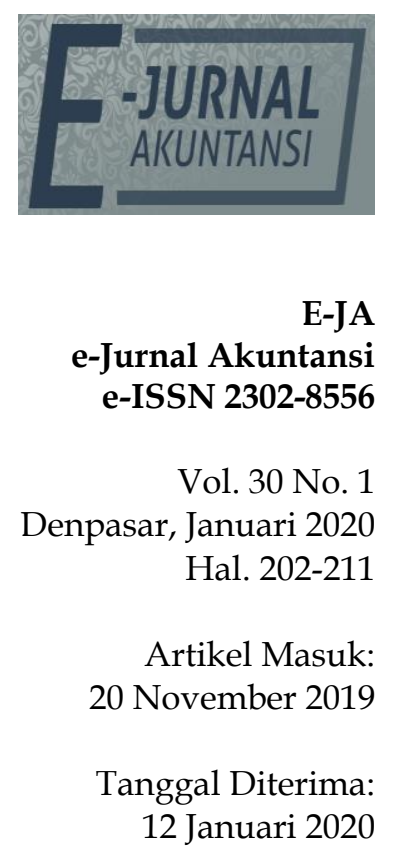

12 Januari 2020 


\section{INTRODUCTION}

Earnings is the concern of potential investors and investors to assess the company. Investors need quality earnings to value the company. Persistent Earnings is one of the characteristics of quality earnings. Persistent earnings are earnings that reflect the sustainability of future earnings (Penman \& Zhang, 2002). Earnings persistence can be viewed from two perspectives, namely the persistence of earnings generated by the company and the persistence of the performance of stock prices in the capital market (Fanani, 2010). The first view states that persistent Earnings is shown by the long-term sustainability of earnings. Persistent earnings indicate a company's long-term sustainable performance, so that current year's earnings can be used to estimate future earnings (Penman \& Zhang, 2002; Richardson, 2003) and relate to operating cash flows in the future (Cohen, 2005; Dechow \& Dichev, 2002). The second view is earnings persistence shown by the relationship between earnings and returns. The higher the relationship of earnings with returns, the higher the persistence of earnings (Lev \& Thiagarajan, 1993).

Earnings as an important indicator for investors in assessing the company has been engineered by company management to attract investors to invest in company shares. This view is consistent with agency theory that explains the differences in interests between management and investors, as well as the asymmetry between management and the company. Management has wider information than investors about the company, whereas investors have limited information related to the truth of the information presented in the financial statements (Amelia \& Yudianto, 2016). Management trying to maximize their interests by way of earnings management. Companies that conduct earnings management will have lower earnings persistence (Adiati \& Rahmawati., 2015). This is due to the lower persistence of accruals in companies that do earnings management than companies that do not do earnings management.

This study tries to examine the existence of book-tax different mediation on the effect of earnings management on earnings persistence. Earnings management is suspected of influencing the book tax differential reported in the company's financial statements. The tax different book is a signal of earnings management (Hanlon, 2005), so it can be used to detect earnings management (Sari \& Purwaningsih, 2016). Book tax different is the difference between accounting profit and fiscal profit. This difference occurs due to differences in the measurement of fiscal earnings and accounting earnings. Fiscal profits are prepared in accordance with tax regulations which give management less discretion in determining accruals than financial accounting standards. Thus, fiscal profit can be used as a standard for evaluating accounting profit (Hanlon, 2005). Book tax diferent occurs due to earnings management carried out by management. High book difference will reduce the company's earnings persistence (Adiati \& Rahmawati., 2015; Hanlon, 2005; Heri Prasetyo \& Rafitaningsih, 2015).

Based on the background of the problems that have been described previously earnings persistence will decrease due to earnings management. This study examines whether earnings management by management increases booktax differentials and then reduces earnings persistence. The specific objectives of 
the study are (1) to examine the effect of earnings management on earnings persistence, (2) to examine the effect of earnings management on book tax different, and (3) to examine the effect of book tax different on earnings persistence.

Agency theory states that company management will maximize its interests. Asymmetry asymmetry between management (agent) and investor (principal) and management efforts to maximize interests will encourage management to conduct earnings management. Management is carried out management through the flexibility of accounting choices in financial accounting standards. Management will have the discretion to choose accounting policies to achieve the expected level of profit.

Earnings management decreases earnings persistence. Earnings resistance is determined by the content of the accruals and cash flow in the current period earnings (Fanani, 2010). The accrual component which is less stable and persistent over time will reduce the persistence of earnings. Accrual persistence will decrease due to earnings management which will have an impact on earnings persistence. Earnings management is proven to be related to earnings resistance (Adiati \& Rahmawati., 2015). The higher the earnings management practices undertaken by management, the lower the earnings resistance. Based on agency theory and the results of research by Adiati \& Rahmawati. (2015), the following hypothesis can be formulated.

$\mathrm{H}_{1}$ : Earnings management negatively affects earnings persistence.

Book tax differences occur due to differences in recognition and measurement of financial statement elements between financial accounting standards and tax regulations. Differences can be permanent and temporary. Permanent differences arise as a result of certain income and expenses recognized according to financial accounting standards, but not recognized by taxation regulations. These revenues and expenses cannot be recognized in the future. Temporary differences occur from time differences and methods of recognizing income and expenses between financial accounting standards and tax regulations. Temporary differences will be recognized as deferred tax assets or liabilities.

Tax regulations have lower flexibility to manage earnings compared to financial accounting standards. The difference between accounting profit compiled based on financial accounting standards and fiscal profit compiled based on tax regulations can be used to evaluate accounting profit (Hanlon, 2005). A high tax different book indicates earnings containing earnings management (Sari \& Purwaningsih, 2016). Based on these explanations the following hypothesis can be formulated.

$\mathrm{H}_{2}$ : Earnings management has a positive effect on book tax different.

Earnings persistence results from the accrual component and cash flow in the current year's earnings. Low accrual persistence from time to time will reduce the persistence of earnings. Book tax different can take the form of permanent and temporary differences. Temporary differences are thought to have a negative effect on earnings persistence. Temporary differences arise due to differences in time and method of recognition of income and expenses between financial accounting standards and tax regulations. High differences in temporary 
differences result in deferred tax assets or liabilities. The higher the temporary difference, the lower the accrual persistence. The lower the accrual persistence will have an impact on the lower the persistence of earnings. Book tax different proved to have a negative effect on earnings persistence (Adiati \& Rahmawati., 2015; Heri Prasetyo \& Rafitaningsih, 2015; S, Pratomo, \& Nurbaiti, 2017; Wijayanti, 2006). Based on the explanation, the research data were formulated as follows.

$\mathrm{H}_{3}$ : Book tax different has a negative effect on earnings persistence.

\section{RESEARCH METHOD}

The variables of this study consisted of independent variables, dependent variables, and mediating variables. The dependent variable is a variable that depends on the independent variable. The dependent variable of this study is earnings persistence. Earnings persistence is a measure of quality earnings. Persistent earnings will tend to be stable and sustainable or do not fluctuate each period. Earnings persistence can be measured by the regression coefficient for future period accounting earnings with current period accounting earnings (Wijayanti, 2006). The higher the value of the regression coefficient (close to 1), the higher the earnings resistance. Persada \& Martani (2010) calculates earnings persistence with changes in profit before tax for the year consisting of profit before tax this year minus profit before tax the previous year divided by total assets. In this study the authors use the same ratio with the earnings resistance can be measured by changes in profit before tax for the year which consists of profit before tax for the year $(t)$ minus profit before tax in the previous year $(t)$ divided by total assets (Persada \& Martani, 2010).

The independent variable of research is earnings management. Earnings management is an action taken by management to manipulate earnings by utilizing available accounting options in accordance with financial accounting standards and taking the right choices to achieve the expected level of profit (Belkoui, 2007). Earnings management in this study was measured by a discretionary accruals (DAC) proxy which was calculated by a modified Jones model (Dechow, Hutton, Kim, \& Sloan, 2012). This model uses total accrual (TAC) which is classified as a component of discretionary accruals (DAC) and non discretionary accruals (NDAC).

Mediation variables or intermediate variables are variables that are between independent and dependent variables. The independent variable indirectly affects the dependent variable through mediating variables. The mediating variable of this study is book tax different. Book tax differences are differences in accounting earnings and fiscal earnings. Accounting profit before tax represents net profit or loss for one period before deducting tax expense calculated based on financial accounting standards. Accounting profit is beneficial for investors and creditors to assess economic performance. Fiscal profit is profit or loss for a period calculated based on taxation regulations and is intended to be the basis for calculating income tax. Due to differences, each entity is required to make fiscal corrections.

The population of this study is companies listed on the Indonesia Stock Exchange. The sample of this research is manufacturing companies listed on the 
Indonesia Stock Exchange in 2012-2018. The selection of manufacturing companies as a sample of this research is because manufacturing companies are large enough to be considered representative of companies listed on the Indonesia Stock Exchange. Another reason for choosing a sample is only manufacturing companies because companies in the financial services industry are very vulnerable to regulation. In addition, companies in the hospitality, travel, transportation and real estate industries have different financial characteristics from manufacturing companies (Joni and Hartono, 2008).

The sampling method used is purposive sampling. The sampling criteria in this study are (1) manufacturing companies listed on the IDX and published audited financial statements in a consistent and complete manner from 20122018. (2) declared in rupiah. The reason is that foreign exchange rates fluctuate, making it difficult to homogenize their values. (3) the company did not experience a loss in the commercial financial statements and fiscal financial statements during the observation year. The reason is that losses can be compensated into the future (carry forward) to reduce the cost of deferred taxes and are recognized as deferred tax assets so that they can obscure the meaning of book tax differences (Hanlon, 2005). (4) The company does not take corporate action.

\section{RESULT AND DISCUSSION}

The total sample of companies that met the criteria was 51 companies, until 357 observations were obtained in the 2012 to 2018 observation period.

Table 1. Sample of Company

\begin{tabular}{ll}
\hline Year & Number of Company \\
\hline Manufacturing Company in 2012 & 51 \\
Manufacturing Company in 2013 & 51 \\
Manufacturing Company in 2014 & 51 \\
Manufacturing Company in 2015 & 51 \\
Manufacturing Company in 2016 & 51 \\
Manufacturing Company in 2017 & 51 \\
Manufacturing Company in 2018 & 51 \\
Total Observation 2012-2018 & 357 \\
\hline
\end{tabular}

Source: Data Processed, 2019

Research variables, including earnings management (ML), book tax different (BTD) and earnings persistence (PL). This study calculates the minimum value, maximum value, average, and standard deviation of 357 observational variables. Data on PL variables are 357 with an average value of 0.0101 with a standard deviation of 0.10222 . This means that the average company earnings persistence is 0.0101 .

Earnings persistence tends to be small, which is 0.10222 . The minimum value for earnings persistence is -1.05 at PT Astra Internasional Tbk. in 2014. The maximum value of earnings persistence of 1.16 is owned by PT Astra International Tbk. in 2013. Data on ML variables measured by accrual expression amounted to 357 with an average value of 0.0916 with a standard deviation of 0.92309. This means that the average management earnings of 0.0916 . The minimum value for ML is -2.82 obtained by SSRN companies in 2016, while the 
maximum value of 0.88 is obtained by MERK companies in 2018. BTD variables are measured by differences in accounting income and fiscal profit. Data on BTD variables amounted to 357 observations with an average value of -0.17 with a standard deviation of 0.06860 . This means that the data on BTD variables have variations that tend to be small. The minimum value for BTD of 12.46 is owned by MERK in 2014, while the maximum value of 15.05 was obtained by JECC in 2014.

Table 2. Descriptive Statistics of Research Variables

\begin{tabular}{llllll}
\hline Variables & $\begin{array}{l}\text { Number } \\
\text { Sample }\end{array}$ & $\begin{array}{c}\text { ofMinimum } \\
\text { Value }\end{array}$ & $\begin{array}{l}\text { Maximum } \\
\text { Value }\end{array}$ & Average & $\begin{array}{l}\text { Standard } \\
\text { Deviation }\end{array}$ \\
\hline PL & 357 & $-1,05$ & 1,16 & 0,0101 & 0,10222 \\
ML & 357 & $-2,82$ & 6,38 & 0,0916 & 0,92309 \\
BTD & 357 & $-0,17$ & 0,88 & 0,0153 & 0,06860 \\
\hline
\end{tabular}

Source: Data Processed, 2019

Path analysis is a form of structural model. Path analysis estimates the path coefficients with partial regression in each regression equation (Solimun, 2002: 50). The method used in estimating the regression parameters is the ordinary least squares (OLS). Two regression equations are formulated to estimate the path coefficient, namely:

$\mathrm{BTD}=\mathrm{P}_{11} \mathrm{ML}+\varepsilon_{1}$

$\mathrm{PL}=\mathrm{P}_{12} \mathrm{ML}+\mathrm{P}_{21} \mathrm{BTD}+\varepsilon_{2}$

Where:

ML = earnings management

BTD $=$ book tax different

$\mathrm{PL}$ = earnings persistence

This study tests the assumptions of the path model, namely residual normality test, autocorrelation test, multicollinearity test, and heteroscedasticity test. The assumption test results of the path model prove that each model meets the assumption of normality, there is no autocorrelation, there is no multicollinearity between independent variables, and residual homoscedasticity. The results of testing the second hypothesis $\left(\mathrm{H}_{2}\right)$, the effect of earnings management on book tax different is presented in Table 1. showing a path coefficient of 0.188 . Positive path coefficient sign, in the direction of the predicted $\mathrm{H} 2$ direction. The significance value of $0.013<\mathrm{a}$, so that $\mathrm{H} 2$ is accepted. This study supports $\mathrm{H} 2$, earnings management has a positive effect on book tax different.

This research model involves variable earnings management (ML), book tax different (BTD), and earnings persistence (PL). ML is an independent variable. $\mathrm{BTD}$ is a mediator variable. PL as the dependent variable. The hypothetical model is presented in the path diagram in Figure 1. Estimating the path coefficient uses ordinary least square (OLS) for model 1 and model 2 partially. The path coefficient is a standardized regression coefficient (standardize beta coefficients). OLS is used to determine the influence and strength of influence between research variables. First, this study aims to examine the effect of earnings management (ML) variables on different tax books. Second, this study examines the effect of earnings management (ML) and book tax different (BTD) on earnings persistence (PL). The results of parameter 
estimation to test the effect of earnings management variables (ML) on book tax different (BTD) can be seen in Table 1 .

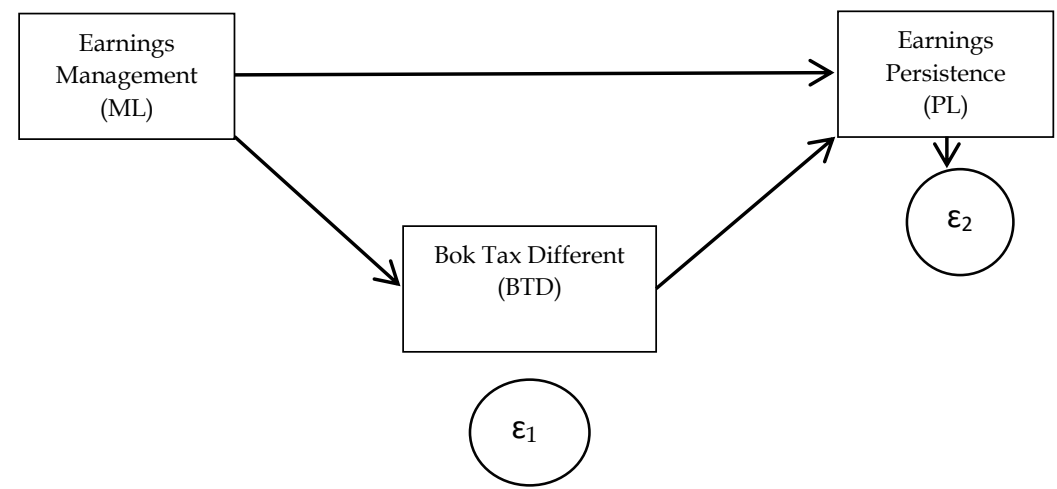

Figure 1. Research Model

Source: Data Processed, 2019

Table 1. shows the direct effect of earnings management (ML) on earnings persistence with a path coefficient of -0.098 . Significance value of $0.066>a$, so the first research hypothesis $\left(\mathrm{H}_{1}\right)$ was rejected. Research shows that earnings management (ML) has no significant effect on earnings persistence (PL).

Table 1. Estimation Results of the Coefficient Parameters

\begin{tabular}{|c|c|c|c|c|c|}
\hline \multirow[t]{2}{*}{ Hypothesis } & \multicolumn{2}{|c|}{ Prediction ofPath } & \multirow[t]{2}{*}{$\mathrm{t}$} & \multirow[t]{2}{*}{ Sig. } & \multirow[t]{2}{*}{ Conclusions } \\
\hline & Direction & Coefficient & & & \\
\hline $\mathrm{ML} \rightarrow \mathrm{PL}\left(\mathrm{H}_{1}\right)$ & - & $-0,098$ & $-1,841$ & 0,066 & $\mathrm{H}_{1}$ reject \\
\hline $\mathrm{ML} \rightarrow \mathrm{BTD}\left(\mathrm{H}_{2}\right)$ & + & 0,188 & 2,51 & $0,013^{*}$ & $\mathrm{H}_{2}$ accept \\
\hline $\mathrm{BTD} \rightarrow \mathrm{PL}\left(\mathrm{H}_{3}\right)$ & - & $-0,143$ & $-2,698$ & $0,007^{*}$ & $\mathrm{H}_{3}$ accept \\
\hline
\end{tabular}

Source: Data Processed, 2019

Check the validity of the model using the coefficient of total determination $\left(R^{2} \mathrm{~m}\right)$. The coefficient of total determination $\left(\mathrm{R}^{2}\right.$ total $)$ is the coefficient of determination of all endogenous variables with the following formula:

$\mathrm{R}_{\text {total }}=1-P \mathrm{e}_{1}{ }^{2} \cdot \mathrm{Pe}_{2}{ }^{2}$

Pe1 $=0.982$ and $\mathrm{Pe} 2=0.986$, so the total determination coefficient (R2total) can be calculated as follows.

$\mathrm{R}^{2}$ total $=1-0,982^{2} \cdot 0,986^{2}=0,061$

The coefficient of total determination ( $\mathrm{R}^{2}$ total) of 0.061 means that the information contained in the $6.1 \%$ data can be explained by the analysis model of the relationship between variables, while the remaining $93.9 \%$ by other factors not included in this study. BTD is thought to mediate the influence of ML on the PL. The indirect effect (mediating effect) through BTD differences can be seen from the multiplication of the path coefficients of ML influence on BTD and the influence of BTD on PL. The path coefficient of ML influence on BTD in Table 4.9 is 0.188 (significant, $\mathrm{H}_{2}$ ) and the coefficient of influence of BTD difference on PL is -0.143 (significant, $\mathrm{H}_{3}$ ). Thus the coefficient of indirect effect between ML on PL through BTD $0.188 \times-0.143=-0.0168$. Because both path coefficients are significant, the indirect effect between ML on PL through BTD is significant. This shows that BTD mediates the influence of ML on the OT. The mediating effect of BTD in the form of full mediation (full mediation) because the direct influence of 
ML on PL is not significant, but the indirect effect of ML on PL through BTD is significant. This indicates that ML will affect the OT if there is a BTD.

The results of hypothesis testing $\left(\mathrm{H}_{1}\right)$ failed to support $\mathrm{H}_{1}$ which states earnings management has a negative effect on earnings persistence. This study found no direct effect of earnings management on earnings persistence. The results of the study do not support previous studies that found earnings management to reduce earnings persistence, because earnings peristence is determined by the accrual content and cash flow in the current period earnings (Fanani, 2010). The accrual component which is less stable and persistent over time will reduce the persistence of earnings. Accrual persistence will decrease due to earnings management which will have an impact on earnings persistence. The results of the study do not support previous research, which found earnings management is associated with earnings resistance, such as Adiati \& Rahmawati. (2015).

The results of hypothesis testing $\left(\mathrm{H}_{2}\right)$ support $\mathrm{H}_{2}$ which states that earnings management has a positive effect on book tax different. Book tax differences occur due to differences in recognition and measurement of financial statement elements between financial accounting standards and tax regulations. Differences can be permanent and temporary. Permanent differences arise as a result of certain income and expenses recognized according to financial accounting standards, but not recognized by taxation regulations. These revenues and expenses cannot be recognized in the future. Temporary differences occur from time differences and methods of recognizing income and expenses between financial accounting standards and tax regulations. Temporary differences will be recognized as deferred tax assets or liabilities.

Tax regulations have lower flexibility to manage earnings compared to financial accounting standards. The difference between accounting profit compiled based on financial accounting standards and fiscal profit compiled based on tax regulations can be used to evaluate accounting profit (Hanlon, 2005). The results of this study support the study of Sari \& Purwaningsih (2016) who found a high tax different book indicating earnings containing earnings management.

The results of hypothesis testing $\left(\mathrm{H}_{3}\right)$ support $\mathrm{H}_{3}$ which states that book tax different has a negative effect on earnings persistence. Earnings persistence results from the accrual component and cash flow in the current year's earnings. Low accrual persistence from time to time will reduce the persistence of earnings. Book tax different can take the form of permanent and temporary differences. Temporary differences are thought to have a negative effect on earnings persistence. Temporary differences arise due to differences in time and method of recognition of income and expenses between financial accounting standards and tax regulations. High differences in temporary differences result in deferred tax assets or liabilities. The higher the temporary difference, the lower the accrual persistence. The lower the accrual persistence will have an impact on the lower the persistence of earnings. The results found that book tax different had a negative effect on earnings persistence. Similar results were obtained by Adiati \& Rahmawati (2015); Heri Prasetyo \& Rafitaningsih (2015); S et al. (2017); Wijayanti (2006). 


\section{CONCLUSION}

This study examines the effect of earnings management directly on earnings persistence, and the indirect effect of earnings management through book-tax differentials on earnings persistence. The results of hypothesis testing (H1) failed to support $\mathrm{H} 1$ stating that earnings management had a negative effect on earnings persistence. The results of hypothesis testing (H2) support $\mathrm{H} 2$ which states that earnings management has a positive effect on different tax books. The results of hypothesis testing $(\mathrm{H} 3)$ support $\mathrm{H} 3$ which states that the book tax has a different negative effect on earnings persistence. Earnings persistence results from the accrual component and cash flow in the current year's earnings. Low accrual persistence from time to time will reduce the persistence of earnings. Book different taxes can take the form of permanent and temporary differences. Temporary differences are thought to have a negative effect on earnings persistence.

Based on the results of the study can be taken several suggestions for investors. Earnings persistence is very important for investors in predicting the company's duration. Earnings persistence can be predicted by paying attention to different tax books. The higher the book tax is different, the lower the persistence of earnings will be.

\section{REFERENSI}

Adiati, A. K., \& Rahmawati. (2015). Manajemen Laba, Large Book-Tax Differences, dan Persistensi Laba. In Seminar Nasional Akuntansi. Medan: Ikatan Akuntan Indonesia.

Amelia, N., \& Yudianto, I. (2016). Pengaruh Book-Tax Differences terhadap Kualitas Laba dengan Manajemen Laba sebagai Variabel Intervening. Jurnal Akuntansi Dan Keuangan.

Belkoui, A. R. (2007). Teori Akuntansi Edisi 5. Jakarta: Salemba Empat.

Cohen, D. A. (2005). Quality of Financial Reporting Choice: Determinants and Economic Consequences. SSRN Electronic Journal. https://doi.org/10.2139/ssrn.422581

Dechow, P. M., \& Dichev, I. D. (2002). Quality Earnings: The The Accruals Accrual Estimation Errors. The Accounting Review.

Dechow, P. M., Hutton, A. P., Kim, J. H., \& Sloan, R. G. (2012). Detecting Earnings Management: A New Approach. Journal of Accounting Research. https://doi.org/10.1111/j.1475-679X.2012.00449.x

Fanani, Z. (2010). Analisis Faktor-Faktor Penentu Persistensi Laba. Jurnal Akuntansi Dan Keuangan Indonesia. https://doi.org/10.21002/jaki.2010.06

Hanlon, M. (2005). The persistence and pricing of earnings, accruals, and cash flows when firms have large book-tax differences. Accounting Review. https://doi.org/10.2308/accr.2005.80.1.137

Heri Prasetyo, B., \& Rafitaningsih, R. (2015). Analisis Book Tax Differences Terhadap Persistensi Laba, Akrual Dan Aliran Kas Pada Perusahaan Jasa Telekomunikasi. JIAFE (Jurnal Ilmiah Akuntansi Fakultas Ekonomi). https://doi.org/10.34204/jiafe.v1i1.293Lev, B., \& Thiagarajan, S. R. 
(1993). Fundamental Information Analysis. Journal of Accounting Research. https://doi.org/10.2307/2491270

Penman, S. H., \& Zhang, X. J. (2002). Accounting conservatism, the quality of earnings, and stock returns. Accounting Review. https://doi.org/10.2308/accr.2002.77.2.237

Persada, A. E., \& Martani, D. (2010). Analisis Faktor Yang Mempengaruhi Book Tax Gap Dan Pengaruhnya Terhadap Persistensi Laba. Jurnal Akuntansi Dan Keuangan Indonesia. https://doi.org/10.21002/jaki.2010.12

Richardson, S. (2003). Earnings quality and short sellers. Accounting Horizons. https:/ / doi.org/10.2308/acch.2003.17.s-1.49

S, A. S., Pratomo, D., \& Nurbaiti, A. (2017). Pengaruh Book Tax Differences Dan Aliran Kas Operasi Terhadap Persistensi Laba. Jurnal Akuntansi. https://doi.org/10.24912/ja.v20i2.61

Sari, D. P., \& Purwaningsih, A. (2016). Pengaruh Book Tax Differences Terhadap Manajemen Laba. MODUS. https://doi.org/10.24002/ modus.v26i2.583

Wijayanti, H. (2006). Analisis Pengaruh Perbedaan Antara Laba Akuntansi Dan Laba Fiskal Terhadap Persistensi Laba, Akrual, Dan Arus Kas. Simposium Nasional Akuntansi IX. 